\title{
ADSA Presidential Report
}

Phillip S. Tong

Cal Poly State University

It has truly been an honor to serve as president of $\mathrm{ADSA}^{\circledR}$ this past year. It was a real pleasure to have worked alongside so many smart, hard-working, and car-

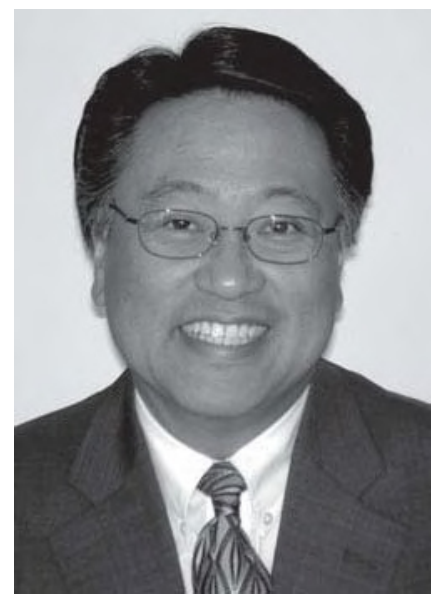

ing ADSA members who generously volunteered their time to serve on the ADSA Board of Directors and ADSA committees, and work on various other activities. Additionally, ADSA and FASS staff provided the continuity and professional service to support, facilitate, and guide us all year. Hence, I am happy to report on some of the highlights of our past year. Overall, some new initiatives were undertaken that will strengthen ADSA's future and we made some noteworthy accomplishments that continue to reinforce ADSA's vision as the society for science, education, and service to the dairy industry.

\section{Journal of Dairy Science ${ }^{\circledR}$}

Ranking. Journal of Dairy Science (JDS ${ }^{\circledR}$ ) has again been ranked number 1 by five-year Impact Factor (Journal Citation Reports published by Thomson Reuters), and number 1 by Eigenfactor Score in the Agriculture, Dairy and Animal Science category (49 journals). Furthermore, JDS is ranked number 11 by Impact Factor and number 12 by five-year Impact Factor in the Food Science and Technology category (118 journals). This truly exceptional performance occurred in the past year under the leadership of Gary Rogers, our editor-in-chief, and his fantastic team of senior and section editors, our reviewers, Editorial Board, the Journal Management Committee, and the FASS editorial and production staff. This group of individuals displayed teamwork at its very finest for the benefit of all ADSA members!

After 5 years as editor, Gary asked that we find his successor. After a thorough search for Gary's successor,
Roger Shanks (University of Illinois) was selected as the new editor-in-chief.

Move to Elsevier. With the help of our publishing consultant, Kaufman Wills Group, ADSA entered into a five-year co-publishing agreement with Elsevier, effective January 1, 2010. The purpose of this partnership was to more effectively market and sell JDS around the world using resources and reach unlike anything we could achieve if we were on our own. Key to the agreement was that the FASS publications department would continue to handle the editorial and composition work. Aside from the excellent service and value that FASS provides, this arrangement allows ADSA to control interactions with our authors and reviewers. I want to reassure you that ADSA remains committed to fully utilizing FASS editorial and production services for the Journal of Dairy Science. However, we hope to realize broader reach of JDS with Elsevier's marketing expertise, and ADSA will benefit from guaranteed revenue at a level comparable to that in 2009, the best year JDS has ever had.

We fully expect that Elsevier will deliver new value to our members through this partnership, while protecting JDS from further attrition of institutional subscriptions. We expect to rapidly distribute JDS around the world, improve our Impact Factor, and add to our bottom line, to help us reach the JDS Superfund goal even sooner, via larger association contributions. Such success can only help to ensure a successful JDS for ADSA and FASS.

Page Charges. An initial contribution of $\$ 1.6$ million of ADSA net assets was transferred to the JDS Superfund in 2009. At each annual board meeting, once the annual audit has been completed, the Board decides on the Association's contribution to this fund. This past July, the ADSA Board transferred an additional $\$ 250,789$ to the Superfund. The value of this fund moves with the market, as it is an all-equity fund. As of September 30, 2010, the JDS Superfund stood at $\$ 2,921,249$, well on the way to achieving our $\$ 8$ million goal. This past spring, we opened the second channel of support for the JDS Superfund, via the Foundation, to enable individual and corporate donations. 
The plan is to create a JDS Superfund of $\$ 8$ million to generate a stream of annual investment income to replace member page charges. Zero page charges for members will attract more of the best papers and serve as a strong incentive to become a member of ADSA.

\section{Membership}

Enrollment. ADSA has grown, both in members and total net assets, after multiple years of the worst recession most of us have ever seen. Total membership, of all types, increased by $4.9 \%$ in 2009! ADSA now has six Global Partners for $e$-Membership. Elsevier will promote full and $e$-Membership at conferences it attends on our behalf around the world.

Feedback Surveys. As many of you now know, ADSA engaged in original research, conducting focus groups and web-based surveys of its members and nonmembers. Areas covered since the last time we met include a JDS reader's survey; an international member and nonmember survey; and graduate student research. ADSA is investing in research to ensure that the Board addresses and responds to member needs, based on what our members are telling us. The knowledge gained will enable ADSA to undertake new strategic initiatives in 2010-2011 that are targeted to member needs.

\section{ADSA Foundation}

After a review of the research findings compiled by our fundraising consultants, the Foundation Board of Trustees reoriented its funds to student support. An annual giving campaign was launched in May, and I hope everyone who has not yet had the chance will make a contribution soon. The Foundation website is easy to find, now that we created a button in the menu bar of the ADSA home page, and it's easy to make a donation by credit card. Just select Foundation, and then click the Make a Donation link - it's that simple.

Discover Conferences. Under the leadership of Larry Miller, and with the support of Molly Kelley, the Foundation held four highly successful Discover Conferences since the last Annual Business meeting.

$\boldsymbol{S}-\boldsymbol{P A} \boldsymbol{C}$. Thanks to the efforts of Ken Olson, S-PAC has grown to include 36 conferences and 324 sets of proceedings. I am happy to report that S-PAC is now operating in the black, thanks in part to our offering a calendar-year subscription as part of 2010 dues renewal.

\section{Communications}

ADSA undertook an important new initiative this year, designed to position us as the global "go-to" orga- nization for dairy science and to give ADSA and dairy science a voice in the trade press, consumer media, and with public policy makers. ADSA now issues press releases that highlight the science of our members. Spokespersons have been trained to address six science policy areas of interest to ADSA. Next, ADSA will create its own Science Policy Committee to help ensure that we maximize our investment in FASS Science Policy and to address science policy activities unique to dairy science.

In addition, ADSA began delivery of a weekly industry e-newsletter earlier this year! Be sure to tell us what you think about it by using the e-mail link at the top of the newsletter.

\section{Joint Annual Meeting}

The joint annual meeting (JAM) this year was a huge success by all measures. Total attendance was 3,927, and there were 1,163 oral presentations, 47 symposia, and approximately 1,000 posters at this year's meeting. The Johne's Disease Integrated Program was a new addition to our meeting this year. And due to the tremendous assistance of Karen Plaut, a key highlight of the meeting was the visit by Dr. Roger Beachy, Director of the National Institute of Food and Agriculture, where he spent the day getting to know our membership and ADSA's activities.

Over the past year, we held discussions with the leadership of the American Society of Animal Science (ASAS) to explore ways to ensure that JAM remains the premier meeting for our members. Through these meetings, ASAS and ADSA reaffirmed their commitment to holding a joint annual meeting. In addition, ADSA and ASAS agreed to form a six-member joint annual meeting strategic planning committee to study and provide recommendations on how to improve the JAM. The findings of this committee are expected in 2011.

\section{ADSA Business and Administration}

$\boldsymbol{A} \boldsymbol{D S A}$ Board. A major change since I took office has been to re-orient the board to become a strategically focused board that makes data-driven decisions. As a result, we discuss a "mega issue" topic at every board meeting, and then focus on strategic initiatives, with every ADSA Board member assigned to 1 of our 6 strategic plan goals. To ensure that ADSA's governance structure supports our strategic plan, a top-to-bottom review of our committees was undertaken by our vicepresident, Jim Linn. As a result, some committees have been consolidated, others eliminated, and two important new committees have been formed: the Science Policy and Audit committees. 
Finances. ADSA is very strong from a financial viewpoint, and this allows us to invest in making your valued association with us ever more valuable. As of September 2010, ADSA is close to reaching $\$ 5$ million in total assets (including the JDS Superfund), with only a tenth of that sum in liabilities, most of which is deferred revenue.

$\boldsymbol{A D S A}$ Staff. On the personnel front, ADSA renewed Peter Studney's contract with a three-year term, and Cara Tharp and Vicki Paden, who are FASS employees, continue to provide excellent support to our organization. ADSA's overall relationship with the FASS staff, our primary service provider, is positive and productive, which is essential to ADSA delivering the journal, the joint annual meeting, and many other products and services. At the same time, ADSA is blessed with the talents and dedication of three key independent contractors: Larry Miller, Molly Kelley, and Ken Olson. We have a fantastic team in place and the continuity to keep ADSA moving forward in pursuit of its goals.

\section{Summary}

In total, ADSA is a strong, healthy organization. ADSA is in as good a shape financially as it has ever been. Our journal continues to be ranked among the highest in the field. We continue to hold a highly successful annual meeting. Our board and the various ADSA committees are functioning well to move new initiatives forward to serve the members. Our support personnel at ADSA and FASS are outstanding and our broader volunteer workforce is magnificent. SPAC, ADSA Foundation, and Discover conferences have all had another successful year. Most important of all is that our members remain committed to keeping ADSA the premier scientific organization for the dairy industry. Thank you again for giving me this privilege to serve you this year and, most of all, thank you for all your support and hard work that make ADSA such a special organization! 